\title{
ASSESSMENT OF CONSUMER PREFERENCE AND CONSUMPTION PATTERN OF FLAVOURED MILK AMONGTHE CONSUMERS IN JAIPUR CITY
}

\author{
MOLSHREE RATHORE ${ }^{1}$, DAMANDEEP KAUR ${ }^{2}$ \& JOLLY MASIH ${ }^{3}$ \\ ${ }^{1}$ National Nutrition Consultant and Co-Convenor Indian Dietetics Association, Rajasthan Chapter \\ ${ }^{2}$ DaDa Analtix Pvt Ltd, India \\ ${ }^{3}$ Prestige Institute of Engineering Management, Indore, India
}

\begin{abstract}
Everybody knows about the importance of milk and its relation to good health. Its versatility allows it to be consumed hot or cold, to be used to make milkshakes and smoothies, and to be added tocoffees, teas and hot cocoa for added nutritional value. Flavoured milk is the second largest widely consumed liquid dairy product after plain milk. The concept of flavoured milk is not new to India. Forcenturies Indians had their milk flavoured with traditional condiments, like ellaichi (cardamom), kesar(saffron), badam (almonds), etc. Besides flavour these drinks were also consumed for their health benefits. A study was conducted on the 'Quality Assessment of Branded Flavoured Milk sold in Jaipur City' to analyse the consumer preference. The results revealed that 90 percent of the respondents preferred flavoured milk than other beverages and most of them opted branded flavoured milk. The most preferred flavour milk by the consumers was chocolate flavour.

Keywords: Consumers, beverages, ingredients, nutritional value, nutrients, preference
\end{abstract}

Received: May 18, 2021; Accepted: Jun 08, 2021; Published: Jul 12, 2021; Paper Id.: IJASRDEC202112

\section{INTRODUCTION}

After water, milk is one of the most widely consumed liquids in the world. Everybodyknows about the importance of milk and its relation to good health. When a child is born his/her first food is milk and almost every childis taught about the benefits of drinking milk. Around 6 billion people consume milk or its products such as cheese, butter, cream, curd, etc. daily. It is one of the main ingredients in a number of beverages and foods. Milk comes inmany varieties and its health benefits are well- researched and documented. Its versatilityallows it to be consumed hot or cold, to be used to make milkshakes and smoothies, and to be added to coffees, teas and hot cocoa for added nutritional value. According to the US Department of Agriculture milk is a complete meal by itself and should be a part of a person's daily diet and according to National Dairy Council milk is packed with essential nutrients like calcium, protein, potassium, phosphorous,riboflavin, niacin, vitamin A, vitamin D and vitamin B12, and it has more nutrients than anyother single food [1]. According to Ayurveda milk, nourishes all the tissues, promotes balanced emotions, and helps to balance all the 'doshas' (faults). Per day consumption of at least 3 servings of milk or milk products can have a positive impact on health. Research has found that milk and milk products are importantin the prevention of osteoporosis, they reduce cardiovascular disease, decrease incidence of colon cancer, decrease insulin resistance (diabetes) and help with weight management [2].

Consumers today have the choice of a unique variety of "milks". Numerous types of milk, including soy, rice, almond, coconut, sheep's orgoat's milk, and of course cow's milk is available. The plant-based milk products are a great alternative for those who are lactose intolerant or experience discomfort after consuming animal milk. 
Plant-based milks do not carry the same exceptional nutrient profile as cow's milk [3].

Flavoured milk is the second largest widely consumed liquid dairy product after plain milk. Flavoured milk is a sweetened dairy drink made with milk, sugar, colourings and artificial or natural flavourings. It is often pasteurized using ultra-high-temperature (UHT) treatment, which gives it a longer shelf-life than plain milk. For improving the taste and for increasing sales often flavourings are added to milk. Flavoured milk is sold along with milk and other products in the refrigerated dairy case. There are a wide variety of flavours and consistencies to cater forall ages and tastes with a choice of long-life. [4]. Masala or siced milk is a popular beveragein India and Indian subcontinent. Flavoured milk contains all the goodness of pure and fresh milk combined with the sensation of special flavours. Made from double toned milk, these drinks are light and refreshing and capture the great taste of these amazing flavours, and at thesame time without being heavy or too filling. These tasty health boosting drinks, available in $200 \mathrm{Ml}$, are perfect for all occasions in allseasons [5]. Globally, flavoured milk is one of the fastest-growing dairy products. This reflectsthe steady shift of consumers - across all age groups - from synthetic drinks to real and nutritional drinks all over the world [6].Various flavours of milk available are: Strawberry, coffee, chocolate, fruit-punch, apple, banana, chikoo, mango, elaichi, badam, pineapple, kesar-pista and rose. There was already a rise in demand of flavoured milk priorto the outbreak of COVID-19 as the dietary preferences of consumers increasingly inclinedtowards milk. At the same time hygiene- conscious consumers shifted from unpackagedto packaged products. COVID-19 served to heighten this hygiene-awareness, as well as driving e-commerce sales, which also favoured sales of packaged milk [7]. According to FSSAIflavoured milk should be pasreutized, sterilized or boiled and the type of milk should be mentioned on the label.

\section{SIGNIFICANCE OF THE STUDY}

The concept of flavoured milk is not new to India. For centuriesIndians had their milk flavoured withtraditional condiments, like ellaichi(cardamom), kesar (saffron), badam (almonds), etc. Besides flavour these drinks were also consumed for their health benefits. But now, increasing health consciousness among people, economic and demographic changes, including rising disposable incomes, growing proportion of working women, as well as, a greater awareness to the global trends has increased the demand of milk-based drinks. Flavoured milks are being sold in creative packaging, helping to attract new consumers to the dairy aisle. Despite the important nutrient contributions flavoured milk makes to the diet, concerns about the potential effects of the added sugar and flavourings have raised questions regarding its the role in a healthy diet. Moreover, there arenot many studies done on the quality assessment of flavoured milk, therefore, it is very important to assess the consumption pattern and quality of this product which is dayby day gaining so much popularity.

\section{OBJECTIVE}

To determine the consumption pattern of the selected products (flavoured milk) among the consumers in Jaipur city.

\section{REVIEW OF LITERATURE}

A rise in demand of flavoured milk drinks has been seen in past few years specially in cities and health-conscious consumers, many parentsare now shifting from carbonated drinks to flavoured milk drinks for their children [7]. Ina study it was found that children preferred flavoured milk, rather than plain milk [8]. In another study using data from the 1994-96 and 1998 U.S. Department of Agriculture Continuing Survey of Food Intakes by Individuals (CSFII), children who consumed flavoured milk had higher calcium intakes but similar percent energy for total fat and added sugars compared with children who were non- consumers of flavoured milk [9]. 
In a survey of more than 400 family practitioners, dietitians and pediatricians, a majority thought it was important that childrendrink more milk, regardless of whether it was flavoured or unflavoured [10]. A review ofqualitative consumer research conducted in 2005 by NDC suggests both health professionals and parents encouraged their child to drink flavoured milk when away from home. The nutrients in unflavored and flavoured milk including calcium, magnesium, phosphorus, potassium, protein, and vitamin $\mathrm{D}$, are necessary for developing strong bones and teeth as well as for overall health [11]. There isconsistent evidence from several studies suggesting that the inclusion of chocolate or flavoured milk in the diets of children and adolescents has an overall beneficial impact ondiet quality with no adverse effect on weight [12]. Flavored milk has more calories and as much sugar as soda, but milk also has a varietyof minerals and nutrients, including calcium and vitamins A and D [13].

According to a study by global market intelligence Agency, Mintel, It was found that in 2012 around 20 percent of the new products introduced by dairy drink segment was flavoured milk which increased to 43 percent in 2016. The research also revealed that about 64 percent consumers believed that ready-to-drink milk products are a healthier in comparison to fresh milk, 54 percent found it to be a convenient choice and 46 percent said that it ismore hygienic [14].

\section{METHODOLOGY}

\section{Consumer survey}

Fifty respondents comprising of students aswell as adults were selected on the basis of theirwillingness to cooperate in the study. Data regarding the types of flavoured milk that are popular and commonly consumed; their price and reasons for consumption and consumption pattern was collected using a pretested questionnaire.

\section{Data Analysis and Report Writing}

The data thus collected using the above tools and procedures was tabulated and analyzed. Thereafter report writing was done accordingly. The mean was calculated with thehelp of following formula

Mean

$$
\overline{\mathrm{X}}=\frac{\sum \mathrm{X}}{\mathrm{N}}
$$

Where,

$$
\begin{array}{ll}
\overline{\mathrm{X}} & =\text { Mean } \\
\Sigma & \text { X= Number of observations } \\
\mathrm{N} & =\text { Total Number }
\end{array}
$$

\section{RESULTS AND DISCUSSION}

\section{Objective}

To determine the consumption pattern of the selected products (flavoured milk) among the consumers in Jaipur city.

Fifty respondents comprising of college going students and young adults were selected and surveyed on the basis of their willingness to co- operate in the study. The information regarding consumption pattern of the two most popular brands of flavored milk in Jaipur was collected. 
Table 1: Distribution of the Subjects, According to the Consumption of Flavoured Milk

\begin{tabular}{|c|c|c|}
\hline Response & Yes & No \\
\hline $\begin{array}{c}\text { No. of } \\
\text { consumers }\end{array}$ & $45(90)$ & $5(10)$ \\
\hline
\end{tabular}

$\mathrm{N}=50$; Figures in parenthesis show percentage

The result of the survey show, that 45 out of 50subjects interviewed consumed flavoured milk, and only 10 percent i.e. 5 subjects did not buy /consume flavoured milk. The reason for this high number of flavoured milk consumption may be due to the increased awareness and knowledge of benefits of the product among therespondents.

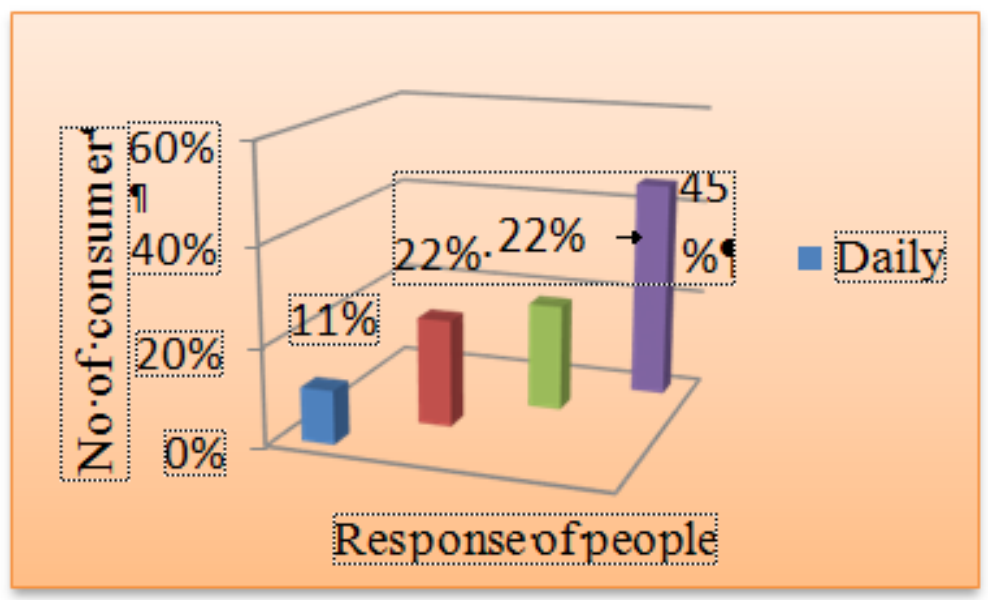

Source: Self computed

Figure 1: Showing Percentage of Frequencyof Consumption of Flavoured Milk. $(\mathbf{N}=45)$

The results of the consumption frequency show, that most of the respondents i.e. 45 percent consume flavoured milk occasionally (less than once a week), 22 percent of the respondents consume flavoured milk weekly, 22 percent consume it thrice a week and only 11 percent ofthem consume it daily.

Similarly, a study was also done on socio economic stipulation of the consumers of flavoured milk and the results indicated for frequency of consumtion of flavoured milk indicated that maximum number of consumers consumed flavoured milk occasionally than daily [15].

Table 2: Distribution of The Subjects, According to their Brand Preference

\begin{tabular}{|c|c|c|c|}
\hline Response & Brand A & Brand B & Others \\
\hline $\begin{array}{c}\text { No. of } \\
\text { consumers }\end{array}$ & $28(63)$ & $11(24)$ & $6(13)$ \\
\hline
\end{tabular}

$\mathrm{N}=45$; Figures in parenthesis show percentage

The above table and figure clearly show that 28 consumers out of 45 said that they preferred Brand A flavoured milk, 11 consumers preferred Brand-B and remaining 6 people had a preference for other brands of flavoured milk. Therefore, the preference for Brand A was maximum accounting for 63 percent of the totalrespondents. The results of the study by Dr.P.Raja indicated that about 26.66 per cent of consumers consumed Amul brand followed byHeritage (25.83per cent), Britannia (30 per cent), Nestle (14.16 percent) and about 7.3 per cent of the consumers consume the Arokia brand [15]. 


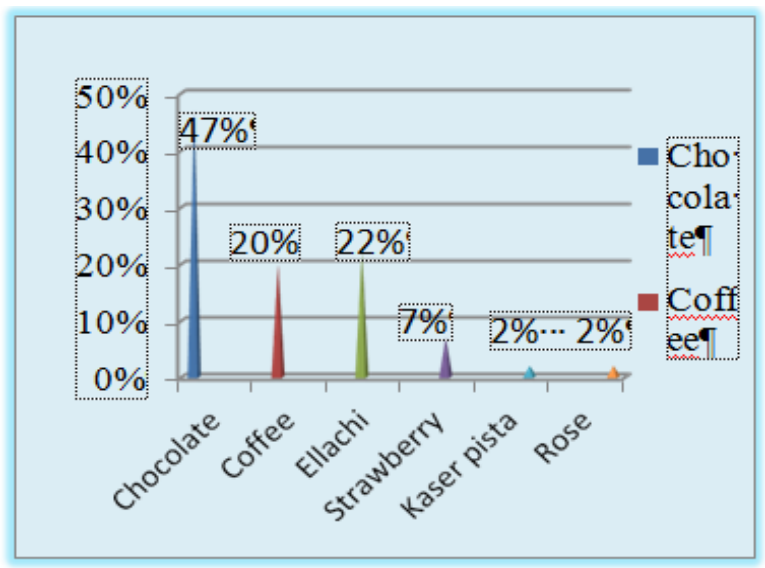

Source: Self Computed

Figure 2: Showing Percentage of Favourite Flavour of Flavoured Milk among the Consumers. (N=45)

As it is clearly seen in the above figure chocolate was the most favourite flavour, 47 percent consumers preferred it to other flavourswhereas kesarpista and rose were the least preferred flavours accounting for only 2 percentliking for each. Coffee, elaichi and strawberry were the favourite flavours of 20 percent, 22 percent and 7 percent consumers respectively. In a similar study, the results indicated that about 24.07 per cent of consumers like Badam flavor followed by Elaichi (20.75), Chocolate (15.77per cent), Strawberry (11.62), Rose Milk (11.62) and about 6.64 per cent of the consumers like Pista flavour[15]. In another study, flavored milk especially with chocolate taste had the potential to increase the children's milkconsumption at school or home. Chocolatewas the preferred flavor, and although unflavored milk was available, it was typically the least popular [8]. This study was also supported by previous research [9].

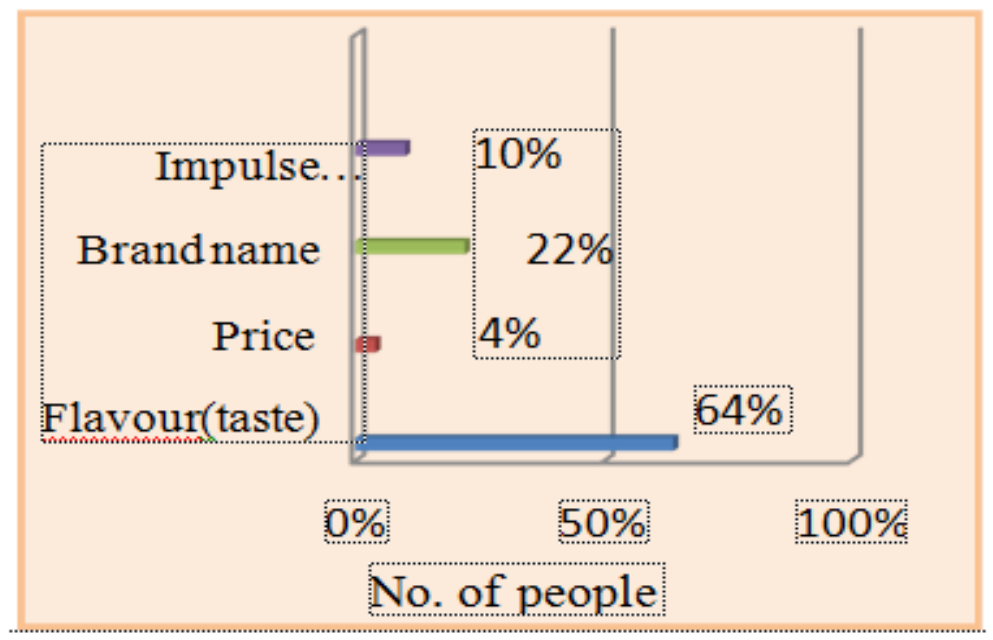

\section{Source: Self Computed}

Figure 3: Showing Percentage of ReasonsWhich Makes Consumers Buy Flavoured Milk. (N=45)

More than half of the respondents (64 percent) feel that taste was the factor which influence them the most for the consumption of flavouredmilk, for 22 percent it was the brand name which was the reason for buying the product, whereas; for 10 percent of the respondent, it was just an impulse purchase and only 4 percent of them considered price as a factor which effects their choice of flavoured milk. According to Dr.P.Raja in overall, the brand of the flavoured milks' taste, colour, flavour, package, availability, price, good quality, and thickness were satisfied with the consumer. Theresults also indicated that noticing of flavouredmilks taste was highly satisfied, and flavour, package, availability, price, good quality, 
thickness was satisfied while colour of the flavoured milk was neither satisfied nor dissatisfied [15].

Table 3: Distribution of RespondentsAccording to their Choice for Buying Flavoured Milk

\begin{tabular}{|l|c|c|}
\hline \multicolumn{1}{|c|}{ Response } & Menu & Display \\
\hline $\begin{array}{l}\text { No of } \\
\text { consumers }\end{array}$ & $21(47)$ & $24(53)$ \\
\hline
\end{tabular}

$\mathrm{N}=45$; Figures in parenthesis show percentage The above table and figure show that 53 percentof the respondents choose flavoured milk fromthe display while 47 percent preferred checkingthe menu before making a choice.

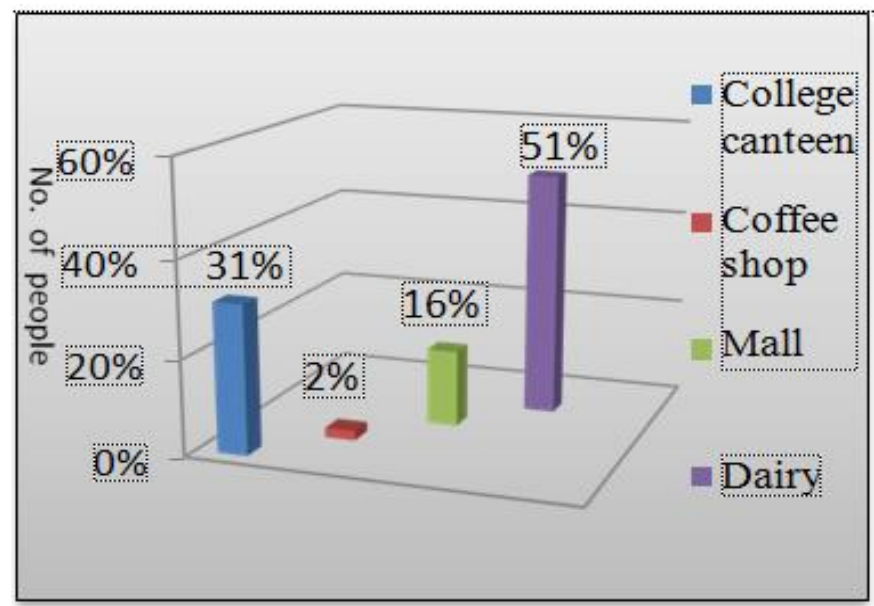

Source: Self computed

Figure 4: Showing Percentage of Places from Where Consumers Buy Flavoured Milk.(N=45)

The responses from the consumers reveal that 23 (51 percent) of the respondents buy flavoured milk from dairy, 14 (31 percent) fromcollege canteen, 7 (16 percent) from mall and only 1 ( 2 percent) from coffee shop. Sinceflavoured milk is a dairy product therefore mostof the consumers prefer buying it from the dairybooths only, as they feel that the supply on these booths is regular and the flavoured milk hence available is more fresh than anywhere else.

Table 4: Distribution of the Respondents According to their Knowledge of Nutritivevalue and Quality of Flavoured Milk

\begin{tabular}{|c|c|c|}
\hline Response & Yes & No \\
\hline $\begin{array}{c}\text { No of } \\
\text { consumers }\end{array}$ & $32(71)$ & $13(29)$ \\
\hline
\end{tabular}

$\mathrm{N}=45$; Figures in parenthesis show percentage

A large number i.e. 71 percent of the respondents were sure of freshness of the product they consume while 29 percent of themwere not very sure about the freshness of the product. Expiry date and manufacturing date ismentioned on every product to check freshness.

Table 6: Distribution of the Respondents According to the Satisfaction with the Hygienic Condition of the Place of Flavoured Milk

\begin{tabular}{|c|c|c|}
\hline Responses & Yes & No \\
\hline $\begin{array}{c}\text { No of } \\
\text { consumers }\end{array}$ & $40(89)$ & $5(11)$ \\
\hline
\end{tabular}

$\mathrm{N}=45$; Figures in parenthesis showpercentage 
Out of 45 respondents surveyed, 40 respondentswere satisfied with hygiene condition of the place from there they buy flavoured milk while 5 of them did not feel so. Thus, a large numberi.e., 89 percent were satisfied with the hygienic condition of the place from where they bought the product or may be most of them checked forthe hygienic condition before buying.

\section{SUMMARY AND CONCLUSION}

Table 5: Distribution of the Respondents According to the Surety about the Freshness of Flavoured Milk

\begin{tabular}{|c|c|c|}
\hline Response & Yes & No \\
\hline $\begin{array}{c}\text { No of } \\
\text { consumer }\end{array}$ & $37(82)$ & $8(18)$ \\
\hline
\end{tabular}

$\mathrm{N}=45$; Figures in parenthesis show percentage

As clearly seen in the above figure most of the respondent, 82 percent said that they were aware of nutritive value and quality of brands they buy while 18 percent of them did not haveany kind of knowledge regarding the nutritive value and quality of flavoured milk they consumed.

The study conducted on the assessment of consumer preference of flavoured milk sold in Jaipur City was carried out in two phases. In thefirst phase the reviews were collected and tools for data collection were prepared and the second phase delt with collection of data (through consumer survey and analysis of samples)

The result showed that 90 percent of the respondents interviewed consumed flavoured milk out of which only 11 percent consumed itdaily and most of them i.e. 45 percent consumed it occasionally Similarly A studywas also done on socio economic stipulation ofthe consumers of flavoured milk and the resultsindicated for frequency of consume flavoured milk indicated that maximum number of consumers consumed flavoured milk occasionally, and minimum frequency was found for daily consumption [15]. This shows that although the preference of consumer has changed with time and knowledge from carbonated beverages to nutritious drinks like flavoured milk but the lower number of daily consumers of flavoured milk suggest that though the consumers are aware of its theneffect yet they are not able to maintain a daily intake routine of health food which provide them with necessary nutrients like protein, calcium, magnesium and vitamin D. About 63 percent of the consumer preferred brand A of flavoured milk, 24 percent opted brand B as their choice and only a few consumers (13 percent) preferred other brands of flavoured milk. Chocolate flavoured milk was the most favourite flavour of the consumer and about 47 percent of the consumer preferred it to other flavours whereas kesarpista and rose were the least preferred flavours accounting for only 2 percent of consumer liking for each. The main reason for buying flavoured milk was the flavour followed by the brand name (22 percent) and impulse purchase (10 percent) in afew cases and only 4 percent of consumer wereaffected by the price of the product as a criterion for purchasing it. The products that aredisplayed catch the consumer eyes easily and attract them for buying it therefore as the resultsshow that for percent of the consumer made a choice from the products displayed rather than going through the menu to get the details of theproducts available and then select them.

Since the product i.e, flavoured milk is a dairy based product therefore most of the buying by the consumers was done from dairies (51 percent) followed by college canteen (31 percent), mall (16 percent) and coffee shop ( 2 percent). Although 82 percent of the respondents said that they had the knowledge ofnutritive value and quality of flavoured milk, but 
when they were asked to illustrate of few knowledgeable facts about the nutritive value of milk or flavoured milk, they were only able to quote of few during the interview section. Most of them said that they would read the labelof the product they consumed and know about the various nutrients present which help them inmaking different choices. The label of all branded products caries expires date andmanufacturing date on it to check for the freshness of the product yet there were 29 percent consumer who were not very sure about the freshness of the flavoured milk they consumed. It is a consumer tendency to first check the hygienic condition of the place wherethey buy food products therefore most of the purchasing of food product is done from places which maintain a good hygienic environment. In the present study 89 percent of the consumers were satisfied with the hygienic condition of the place from where they bought their products. It is imperative that stricter quality control measures be imposed in India toassure that consumers are provided with truly wholesome milk. Therefore, it is highly recommended that hygienic practices should befollowed, regulations and implementation ofHACCP standards, should be done.

Aknowlegdement: Ms. Bhanupriya (Dietician). This paper is a part of dissertation entitled "Consumer Response and QualityAssessment of Flavoured Milk sold in Jaipur city” by Ms. Bhanupriya under the guidance ofDr. Molshree Rathore.

\section{REFERENCES}

1. Patterson, K. Y., Phillips, K. M., Horst, R. L., Byrdwell, W. C., Exler, J., Lemar, L. E., \& Holden, J. M. (2010). Vitamin D content and variability in fluid milks from a US Departmentof Agriculture nationwide sampling to update values in the National Nutrient Database for Standard Reference. Journal of Dairy Science, 93(11), 5082-5090. https://doi.org/10.3168/jds.20103359

2. Thorning, T. K., Raben, A., Tholstrup, T., Soedamah-Muthu, S. S., Givens, I., \& Astrup, A. (2016). Milk and dairy products: good or badfor human health? An assessment of the totality of scientific evidence. Food \& nutrition research, 60,32527. https://doi.org/10.3402/fnr.v60.32527

3. Haas, R., Schnepps, A., Pichler, A., \& Meixner, O. (2019). Cow Milk versus Plant-Based Milk Substitutes: A Comparison of Product Image and Motivational Structure of Consumption. Sustainability, 11(18), 5046. https://doi.org/10.3390/su11185046

4. Tiwari, P.K., Asgar, S., (2017). Diverrsificationin Flavoured Milk: A Review. InternationalJournal of Clinical and Biomedical Research, 3(2) 15-20.

5. Ghodke, A. (2019). Is Flavoured Milk Good For You \& What Are Its Benefits. Awesome Dairy. https://awesomedairy.com/know-about-the-benefits-of-flavoured-milk-and-how-good-it-is-for-youl

6. http://www.agriculturalproductsindia.com/dairy-products/dairy-products-flavoured-milk.html

7. MarketResearch.com.(2020). https://Www.Marketresearch.Com/Euromonit or-International-V746/Drinking-Milk- ProductsIndia-13889535\%.

8. Babolian, H. R. and Ab Karim, M. S., (2010): Factors affecting milk consumption among school children in urban and rural areas ofSelangor, Malaysia International Food Research Journal 17: 651-660.

9. Murphy, M. M., Douglass, J. S., Johnson, R. K., \& Spence, L. A. (2008). Drinking Flavored or Plain Milk Is Positively Associated with Nutrient Intake and Is Not Associated with Adverse Effects on Weight Status in US Children and Adolescents. Journal of the American Dietetic Association, 108(4), 631-639. https://doi.org/10.1016/j.jada.2008.01.004

10. MacDonald, H. B. (2008). Dairy nutrition:What we knew then to what we knownow. International Dairy Journal, 18(7), 774-777. https://doi.org/10.1016/j.idairyj.2008.04.001 
11. Teri Gacek Associates (TGA), (2005): Flavored Milk \& Sugar - Is It An Issue For Moms, Dietitians and Pediatricians? A Qualitative Exploration for Dairy ManagementInc. (DMI). Dairy Council Digest, 79 (6), 31 - 36.

12. Fayet-Moore, F. (2015). Effect of flavored milkvs plain milk on total milk intake and nutrient provision in children. Nutrition Reviews, 74(1), 1-17. https://doi.org/10.1093/nutrit/nuv031

13. Petre, A. (2019). Is chocolate milk goodfor youor bad? https://www.healthline.com/nutrition/chocolate-milk.

14. Mitra, S. (2017). Indians can't get enough offlavoured milk: study. Mint. https://www.livemint.com/Consumer/eeCMH Xv0N9H9TNOJLdUgdN/Indians-cant-get- enough-of-flavoured-milk-study.html

15. Socio Economic Stipulation of the Consumersof Flavored.(2017). Studylib.Net.https://studylib.net/doc/8147318/socioeconomic-stipulation-of-the-consumers-of-flavored 
